Marquette University

e-Publications@Marquette

4-1-1993

Ricardo's Theory of Profit and the Third Edition of the Principles

John B. Davis

Marquette University, john.davis@marquette.edu

Published version. Journal of the History of Economic Thought, Vol. 15, No. 1 (Spring 1993): 90-106. DOI. (C) 1993 Cambridge University Press. Used with permission. 


\section{RICARDO'S THEORY OF PROFIT \\ AND THE THIRD EDITION OF THE PRINCIPLES}

BY

JOHN B. DAVIS

\section{INTRODUCTION}

David Ricardo's “On Machinery" chapter continues to interest theorists and historians of economic thought (Blaug 1958, Hollander 1979, Kurz 1984, Samuelson, 1988, 1989, Morishima 1989, Negishi 1990). Yet the addition of the chapter to the third edition of Ricardo's Principles of Political Economy and Taxation arguably overturns much of the view for which Ricardo is so well known (Davis 1989). In the added chapter Ricardo allows, contrary to his original view in the first two editions, that the introduction of machinery is indeed injurious to the class of laborers. More interestingly, because machinery substitutes for labor, wages cannot rise and profits are no longer threatened by rising rents. Effectively the contest between capitalists and landlords of the first two editions of the Principles is replaced in the final edition by one between capitalists and laborers. However, not only does the "On Machinery" chapter substantially change the distributional argument customarily attributed to the Principles, but it also permits an examination of Ricardo's thinking about distribution in two distinct, but related frameworks. The discussion here compares the distributional analysis in the first two editions with that of the third to explain the general nature of the Ricardo's theory of profit. It does so by providing a novel interpretation of Ricardo's characterization of profit as a residual, and by emphasizing the historical context in which distribution occurred in the beginning of the nineteenth century.

\section{THE DISTRIBUTIONAL ACCOUNT OF THE FIRST TWO EDITIONS}

It is appropriate to begin with Ricardo's view of wages, on account of the special treatment wages receive in the first two editions of the

Marquette University.

Journal of the History of Economic Thought, 15, Spring 1993.

01993 by the History of Economic Society. 
Principles. Similarly to his analysis of the values of commodities, wages are said to be determined by the cost of production (or reproduction) of labor itself: "Labour, like all other things which are purchased and sold, and which may be increased or diminished in quantity, has its natural and its market price. The natural price of labour is that price which is necessary to enable the labourers, one with another, to subsist and to perpetuate their race, without either increase or diminution" (Ricardo I, p. 93). This recalls Ricardo's assertion that the mass of commodities may "be increased in quantity by the exertion of human industry," and "multiplied without any assignable limit" (ibid., p. 12). Yet there is an additional element in Ricardo's account of wages. The natural price of labor, he asserts, also depends on "the quantity of food, necessaries, and conveniences become essential...from habit" (ibid., p. 93). More fully, "it is not to be understood that the natural price of labour, estimated in food and necessaries, is absolutely fixed and constant. It varies at different times in the same country, and very materially differs in different countries. It essentially depends on the habits and customs of the people" (ibid., pp. 96-97). That labor's requirements may vary across time and place suggests that the idea that labor possesses a cost of production understandable in technical or natural terms is severely limited. Indeed, it suggests that Ricardo's reference to the "natural price of labour" borders on being misleading, since reference to a people's "habits and customs" clearly implies a social dimension exists in the determination of the value of labor. However, this theme regarding wages in the early Principles is not significant in the overall distributional analysis Ricardo originally develops, where variations in the relative shares of national income stem only from further extension of the margin of cultivation. In the first two editions of the Principles, then, the price of labor is the natural price of a commodity that may generally be "multiplied without any assignable limit."

With rent one encounters a significantly different sort of treatment. Ricardo explicitly distinguishes his understanding of rent from Smith's cost of production account in insisting that rent is not a cause of a good's exchangeable value, as is the amount of labor required for its production: "If the high price of corn were the effect, and not the cause of rent, price would be proportionately influenced as rents were high or low, and rent would be a component part of price. But that com which is produced by the greatest quantity of labour is the regulator of the price of corn; and rent does not and cannot enter in the least degree as a component part of its price" (ibid., p. 77). Rent is an effect of the level of the corn price, not a cause of that price, and is thus 
price determined rather than price determining. In the second edition of the Principles Ricardo adds a note to this passage emphasizing his departure from Smith: "The clearly understanding of this principle is, I am persuaded, of the utmost importance to the science of political economy" (ibid., p. 77). He then goes on in the text itself to add that his understanding of rent overturns Smith's conclusion that the value of a commodity cannot be determined by the comparative quantity of labor necessary for its production when land has been appropriated, and thus to reject what has since been termed the "adding-up" approach to the value of a commodity, whereby rent, wages, and profits are each a "component part" of the value of a commodity.

It should be emphasized that Ricardo's cost of production theory of the value of commodities does not proceed via the Smithian "addingup" approach, because in Ricardo's view there is something significantly different in the determination of rent than is involved in the determination of wages. Land earns a rent according to the level of the price of corn, and rent is not tied to the cost of production of land, as wages are tied to the cost of production of labor. Indeed, while labor is understood to be continuously reproduced, and thus rewarded in terms of the inputs necessary to that reproduction, land is not produced or reproduced, and is not seen to result from some combination of inputs. Ricardo insists on all this at the very outset of his discussion of rent in his characterization of land itself. "Rent is that portion of the produce of the earth, which is paid to the landlord for the use of the original and indestructible powers of the soil" (ibid., p. 67). In the Essay on Profits it had been the "original and inherent power of the land" (Ricardo $I V$, p. $18 \mathrm{n}$ ). Land, simply, is not the sort of resource that "can be increased in quantity by the exertion of human industry," so that its reward must be determined differently than the rewards to those inputs to production that can be so produced.

Ricardo's account of rent, of course, followed the analysis developed in the work of Malthus, West, and Torrens. With the growth of population and the accumulation of stock, the margin of corn production is continually extended, so that land of a quality inferior to that already in production is continually brought into use. Given that land is "not unlimited in quantity and uniform in quality" (Ricardo $I$, p. 70), the last land brought into production only generates a return sufficient in the value of the corn produced to pay the wages of labor employed upon it plus a return to the capital advanced to pay those wages. This last land earns no rent. Indeed, since the labor required to produce a given quantity of com upon it exceeds that necessary for producing the same quantity of corn on land of higher quality, the better land sells 
the same quantity of corn at a value exceeding its labor content cost of production, and so earns a rent.

In contrast to his more naturalistic cost of production account of wages, then, Ricardo's account of the return to land emphasizes social factors, namely, the institutions of the early nineteenth century system of land tenure and the political arrangements in Parliament and elsewhere that sustained the economic position of landlords. Not emphasized by Ricardo, but no less a part of the social character of land at the time that he wrote, was the fact that though agricultural land possessed economic value, it was still not fully a commodity in the sense of being freely purchased and sold. At the beginning of the nineteenth century most agricultural land still changed hands largely through a system of inheritance. Ricardo presumably did not emphasize the incomplete commodity status of this land because he principally understood commodities to be those items that might be "increased in quantity by the exertion of human industry." We will see, however, that this aspect of land can play an important role in the analysis of Ricardo's theory of profit across the editions of the Principles.

Turning to Ricardo's analysis of profits itself, it should first be noted that Ricardo originally views profit as a residual after wages and rents are determined, rather than a return to capital per se. In the important case of profits in farming, he asserts, "The remaining quantity of the produce of the land after the landlord and labourers are paid, necessarily belongs to the farmer, and constitutes the profits of his stock" (ibid., p. 112). An analysis of profit for Ricardo, therefore, is not a matter of explaining what profit is (where wages are the cost of producing labor's consumption goods, and rent is the produce on inframarginal land), but rather how there may be variations in profit, due to variations in the other distributional shares: "It remains for us to consider what is the cause of the permanent variations in the rate of profit" (ibid., p. 110). Specifically, as the margin of cultivation is extended under accumulation and population growth, the duties imposed on corn imports make inferior land necessary to production. More labor is required to produce a given quantity of corn upon new land, the labor value of corn relative to manufactures is higher, and profits are lower. At the same time, rents increase, "first, because produce would be of a higher value, and secondly, because [landlords] would have a greatly increased proportion of that produce" (ibid., p. 125), since while wages increase in terms of the value of corn, laborers are no better off in real terms, still receiving only the "food and necessaries" required for reproducing their labor.

This much of Ricardo's analysis is familiar. For further illumina- 
tion, the argument can be re-approached from the perspective of an exchange between two different sectors of production, one paying rent and one not, or simply as an exchange between corn and manufactures (we might assume manufacturers pay corn wages). First, however, how did Ricardo understand the exchange between two similar sectors of production, neither of which pays rent? Here he departed from what Smith and many others of his time believed in insisting that any extension or limitation of the exchange between like manufacturing sectors accompanied by improvements in labor productivity was without effect on the profits of either sector. Possessing a more sophisticated view of commodity values than Smith's adding-up view permitted, Ricardo concluded that were costs of production to fall with an increased division of labor and extension of exchange between manufacturing sectors, profit residuals would remain unaffected, because commodity values would fall proportionately to any fall in costs of production.

Questions arise, however, when one turns to exchange between a sector paying rent and one not. Here the extension or limitation of exchange (due to the extension or withdrawal of the margin of cultivation) has definite repercussions on profits. The Principles tells us that as cultivation is extended and exchange increases, profits fall while rents increase. Alternatively, then, should cultivation be reduced and exchange be limited, profits should rise and rents decrease. Yet it is not immediately obvious why this should be so. According to Ricardo's view of profit as a residual, profits rise when a greater residual sum of value is left to capitalists upon the exchange of manufactures and corn. But if withdrawal of the margin of cultivation reduces the value of corn, it would seem that the lower cost of that input should lead to a proportionate fall in the value of manufactures produced with that input, as in the case of the effects of labor productivity gains in exchange between manufactures. This in turn would preclude any increased profit residual, and undermine Ricardo's claims regarding the relationship between rents and profits.

Scholars, of course, have historically focused on what extension of the margin of cultivation meant for profits in Ricardo's argument. This seems to have accorded an inherent plausibility to his analysis of rents and profits, since a higher wage-corn cost of production, with a given labor productivity in manufactures, should surely squeeze profits. However, it also seems to have deflected attention from the case where withdrawal of the margin of cultivation reduces the wage-com cost of production, and from the question of whether potentially increased profit residuals would be competed away, leaving no gain in 
profits to accompany the fall in rents. Ironically, it is probably fair to say that Ricardo was chiefly interested in seeing a contraction of the margin of cultivation (through an end to the corn laws), and that his stagnationist views were essentially alarmist in nature. How, then, might this puzzle of increased profit residuals be explained? The following represents one way in which the matter might be addressed.

Suppose the margin of cultivation is withdrawn, say, on account of free corn imports. Since the commodity values of manufactures must be proportional to their cost of production, manufacturing capitalists could indeed find themselves possessed of an increased residual in the exchange for corn were they be able to purchase corn at a price below its value, while continuing to market their own manufactures as if corn were at its value. The increased residual would then be the difference between the price paid to farmers for corn and its value. Moreover, since farmers (with whom manufacturers exchange) must still, as capitalists, recoup a value for corn proportional to its cost of production, they might, for reasons to yet be explained, reduce rent payments to landlords to make up the shortfall on corn sales, thus effecting the transfer of rents from landlords to capitalists as increased profit residuals that Ricardo would have associated with a withdrawal of the margin of cultivation.

Such an account raises questions of its own. In the first place, if manufacturers purchase corn at a price below its value and cost of production, why would they continue to market their own commodities at a value proportional to the natural value of corn, rather than at a value proportional to the price actually paid for corn? Arguably, the cost of production of manufactures is simply lower in this circumstance, so that the value of manufactures should adjust downward under competition, and profit residuals would then be unchanged. Yet whether manufacturers correspondingly reduce the value of their commodities depends upon whether they believe the lower price paid for corn is temporary or permanent, or in Ricardo's terms, whether corn sells at a lower market price or the natural value of com obtains. If it is the market price, and should the natural value of corn be expected to reassert itself at some later point in time, then manufacturers would be correct to set the value of manufactures at a level proportional to the true value of corn-its natural value - thus temporarily earning increased profit residuals until that time that they must again pay a price for corn equal to its natural value. Moreover, in the circumstances in which the margin of agricultural production is being withdrawn, the value of corn is itself falling with rising labor productivity, so that it is not unreasonable to suppose that, for a time, market forces drive down 
the price of corn faster than does rising labor productivity drive down its value. When finally the margin of agricultural production is again stable, then market forces adjust to the corn cost of production, and the price of corn equals its value. Only in the interim, then, could manufacturers be said to earn increased profit residuals.

A second question concerns the obligations of tenant farmers to landlords. How is it possible that the former simply reduce their payments to the latter, in order to make up temporary shortfalls in corn cost of production? Ricardo is certainly clear that rent is paid according to the differential productivity of marginal and infra-marginal lands, so that tenants were presumably constrained in the adjustments they could make should corn prices fall faster than corn values. Accordingly, though it may be possible to explain the appearance of profit residuals in manufacturing in terms of a discrepancy between market price and value, it appears problematic that rents could be transferred to profits to permit this. Here, Ricardo's opinion about the special character of a sector of production in which rent is paid points toward a solution to these difficulties. As suggested above, agriculture is unique for Ricardo in that land was not fully a commodity in early nineteenth century England. Thus, though landlords could expect to be paid rent on a differential productivity basis, it can be argued that they would not be able to determine, in the interim transitional period during which the margin is contracting, whether tenants actually do maintain such rent payments. Since each landlord possessed limited parcels of land which were almost certainly discontinuous in differential productivity, it would not be easy to establish how fast rents ought to fall across parcels without comparing intermediate parcels in the possession of other landlords. Without a fully developed market for land, this sort of comparison was unlikely made, especially since each landlord had but his own tenants' marketing information to gauge how fast corn values were falling, and thus how fast rents should fall. Should, then, corn prices actually be falling faster than corn values, landlords would expect a decline in rents that unbeknownst to them exactly allowed for the deviation of corn prices below corn values, thus effecting the transfer of rents to profits.

It should be added that tenant farmers would themselves also be unaware of the transfer involved. They would not have reason to believe that corn prices were falling faster than corn values, since they would only perceive changes in the relative prices of corn and manufactures. While corn prices (and values) are falling with the withdrawal of the margin, the prices of manufactures (and their values) are also falling as rising labor productivity in agriculture lowers the cost of 
production in manufactures. Farmers, then, cannot distinguish whether the prices they receive for corn are falling faster than the prices they pay for manufactures, or whether the prices they pay are falling less quickly than the prices they receive. In either event, the upshot is that the cost of production of corn is not falling as fast as would be the case were corn prices not to deviate below corn values, while it is this perceived fall in the corn cost of production that guides the decrease in rents. Indeed, it is highly unlikely that farmers would even have reason to suspect the deviation, since their shortfalls are made good by the reduction in rents.

This analysis clearly goes beyond what Ricardo argued in the Principles. Its strategy of interpretation is to integrate his naturalistic cost of production account of commodities and labor with his more socialhistorical view of the distributional shares of capitalists and landlords by emphasizing the incomplete commodity status of land. In the nineteenth century, however, land was soon to become fully traded in the manner of other commodities, and this presumably would ultimately have eliminated the transfer described above as a source of residual profits. As it turned out, another historical development, the changing importance of machinery and fixed capital in production, stimulated Ricardo in the last edition of the Principles to re-consider elements of his original views, and this re-thinking arguably overturned, at least implicitly, his original conclusions regarding distribution. Thus, the question that remains is whether it is possible to apply the argument about profits above in the new distributional framework of the third edition.

\section{THE DISTRIBUTIONAL ACCOUNT OF THE THIRD EDITION}

How did the addition of the chapter on machinery to the third edition of the Principles reverse the conclusions regarding income shares that Ricardo reached in his first two editions? The introduction of machinery in production, or the replacement of circulating capital by fixed, because it precludes a rise in wages from a rise in the value of corn, allows capitalists to maintain their net incomes despite limited land and a rising population. Since the reduction in circulating capital results in the decline of national or gross income, the fact that net income is unchanged implies that the share of profits in gross income increases. Rather than the accumulation of capital leading to a declining share of profits in gross income, Ricardo's machinery chapter 
analysis indicates that exactly the opposite can be expected.

The impact of the machinery chapter on the original argument of the Principles is perhaps most manifest in terms of the new role rent must assume. Though the added chapter does not change the manner in which rent is determined, rent ceases to be inverse to profits. Quite simply, if capitalists are always able to replace circulating capital with fixed, the demand for labor never increases, and neither wages nor the value of corn can increase. The margin of cultivation is consequently never extended, and rents no longer increase with accumulation and the growth in population. In effect, the perfect substitutability of fixed for circulating capital places a ceiling on wages by expelling labor from production as fast as the demand for circulating capital might increase with accumulation. With less than perfect substitutability, the demand for labor would indeed rise as accumulation increases the demand for circulating capital, though it is fair to suppose that the availability of foreign corn combined with the lesser growth rate of circulating capital associated with some substitution would fundamentally retard the growth of wages. In any event, then, rents would occupy a declining share of national income.

In contrast, the added chapter on machinery implicitly produces an altogether new conception of wages in the Principles. In the chapter, Ricardo begins by allowing that his former position on the impossibility of technological unemployment is mistaken, so that labor may well find itself unemployed when displaced by machinery. This admission clearly disrupts the cost of production-Say's Law treatment of wages of the first two editions. That is, while the Say's Law handling of other commodities remains in force in the third edition, such that commodities found in excess supply in one market are quickly channeled as "savings" into production in other markets as "investments," labor in excess supply, is not similarly reallocated. Since its cost of production is thus not recouped, Say's Law and Ricardo's cost of production approach to value can only jointly be preserved at the expense of sacrificing the cost of production interpretation of the determination of wages.

Ricardo does go to some length in the added chapter in attempting to account for labor's possible reemployment, particularly in private and public services, as if to suggest that his original conception of wages is still appropriate. Nonetheless, as long as technological unemployment is admitted to exist (which was the purpose of the chapter's addition to the Principles), full reemployment is clearly ruled out. Indeed, why would Ricardo have declared the introduction of machinery to create unemployment were that unemployment fully canceled by 
reemployment? In fact, Ricardo's attention to labor's reemployment possibilities itself signals a fundamental change in his conception of wages in that his allowing there exists a role for social debate over how labor is to be reemployed implies that wage determination has become a social matter, rather than simply a function of natural cost of production conditions. It is only in the third edition of the Principles, then, that the customary or habitual element present in the determination of wages noted in the first two editions becomes significant.

This emphasis upon a social element in wage determination is especially clear in the latter half of the added chapter where Ricardo discusses broad policy perspectives for the reemployment of displaced laborers. Indeed, that such reemployment is anything but a strictly natural affair is made particularly clear by his willingness to countenance a social debate over labor's reemployment in which laborers themselves are tentatively offered some say in reaching a consensus on which possibilities ought to be pursued, albeit within the constraint of final decision made by earners of net income. "Independently of the consideration of the discovery and use of machinery...the laboring class have no small interest in the manner in which the net income of the country is expended, although it should, in all cases, be expended for the gratification and enjoyment of those who are fairly entitled to it" (Ricardo $I$, p. 392). Thus, should the wages and conditions of employment in, say, menial service be preferred to the wages and conditions of employment in military service, laborers are invited to express this preference for reemployment, assuming of course that those receiving the net income that is to be spent on such reemployment are indifferent between the alternative forms of expenditure.

That wage determination is fundamentally a social matter, however, need not imply only that the level of wages is itself determined in social debate. The customary or habitual element in the determination of the "food and necessaries" requisite for employment can still be said to establish a relatively unchanging level of wages, while the social dimension underlying this determination could alternatively be said to involve a pattern of social practices among laborers for the utilization of these food and necessaries. The social dimension to wage determination, on this view, would be more a matter of how well laborers made use of a given level of compensation in maintaining their ability to labor. In effect, the social organization of laborers outside capitalist production can be understood to vary across different individuals and/or groups of individuals such that, according to their domestic and community modes of organization, different laborers apply the wage and implied food and necessaries with different de- 
grees of skill or success for their respective maintenance for employment. From this perspective, some laborers would be able to procure their maintenance at the ruling wage without entirely exhausting the food and necessaries received in the wage, while other laborers would but be able to procure their maintenance at the ruling wage by just exhausting the food and necessaries received for the wage. The former would effectively earn rents on the cost of production of maintaining their labor, while the latter would find themselves maintaining their labor at the margin of labor production. Better quality social organization, then, can be said to earn differential productivity rents in labor production just as better quality land does in agricultural production.

While Ricardo did not, of course, elaborate this reformulation of wage determination as reflecting this sort of social component, the account here captures the tenor of his thinking regarding differential rent. It also allows the interpretation of profits residuals above in connection with exchange between a sector earning rent and one not to be re-applied in the third edition of the Principles. Thus, analogously to the account above, a Ricardian theory of profit in the third edition would require that there similarly be an input to the production of labor which is not fully a commodity, much in the same way land was not fully a commodity in corn production. Residual profits would then result as before since capitalists would be able to acquire labor at a price below its value and cost of production when the extent of exchange between capital and labor is decreasing, thus in effect extracting a rent on labor production that is transferred to profits by the temporary deviation of labor's price below its value and cost of production. The continued substitution of machinery for labor on this argument would effectively produce the withdrawal of the margin of "cultivation" of labor, just as the availability of imported corn brought about the withdrawal of the margin in domestic agriculture.

The social organization of laborers thus functions as the input to labor production which, unlike food and necessaries, is not a commodity. This input of course is not tangible in the manner of land in corn production, and it is also not clear which individuals might be thought analogous to tenant farmers in labor families and communities. Still, labor's social organization is certainly no less constitutive of labor production than land is in the production of corn. Further, just as there is no reason to assume that land is homogeneous in quality, so there is just as little reason to assume that social organization among different groups of laborers is homogeneous in quality. Some families, for example, simply make better use of commodities in their produc- 
tion of labor in virtue of their family organization than do others. Those with this advantage accordingly require less commodities than do those less productive in this regard, and thus effectively earn commodity rents on labor production, despite the fact that their social organizational input is not itself quantifiable in commodity terms. In the thinking Ricardo used in first two editions, then, those families earning social organizational rents are inframarginal labor producers. In contrast, those families at the very margin of labor production set the level of the wage relative to the demand for circulating capital at labor's commodity cost of production.

Analogously to Ricardo's analysis of rents and profits in the first two editions of the Principles, the third edition analysis of the Principles sets up an account of profits that makes rents to labor production the source of new profits. Specifically, just as in the first two editions the replacement of domestic corn by foreign corn reduces the demand for the former, thus permitting the withdrawal of the domestic margin of agricultural production, so in the third edition the introduction of machinery substitutes fixed capital for circulating, thus withdrawing the margin of labor production and lowering the demand for labor. Marginal less efficient producers of labor are accordingly eliminated from employment in capitalist production, and the value of labor falls as the higher productivity of formerly infra-marginal labor producers comes to dictate the new location of the margin and the value of labor. Should, accordingly, the transition period to the new, lower value of labor be characterized as one in which for a time the price of labor is falling faster than the value of labor, then labor producers experiencing shortfalls on the cost of production of labor will reduce rent contributions in the interim, thus effecting the transfer from rents to profits displayed in Ricardo's initial reasoning.

Again, capitalists establish their own cost of production according to the value they must ultimately pay for labor, and not according to its price temporarily below value in the transition to the new margin, so that residual profits result from the deviation of prices below values. Producers of labor, on the other hand, are even less likely to recognize the reduction in rents to social organization and the consequent rise in profits than landlords and/or tenant farmers in the analysis of the first two editions. First, it is obviously not the case that two separate groups negotiate differential productivity rents, as do tenants and landlords who proceed by contract, both because the social organization input responsible for rents is so highly intangible, and because the social organization of laborers is established upon affective, customary, and normative grounds which traditionally lack commodity dimen- 
sions. Secondly, as with tenant farmers in the first two editions, that the improved productivity of capitalist commodities reduces their values as the cost of labor production falls makes it difficult for those marketing labor to determine whether the price of labor is falling faster than rising labor productivity, or whether the values of "food and necessaries," the commodity inputs to labor production, are falling less quickly than the value of labor. Again, relative prices are all that the producers of labor have to go on, and the political economists that did take up labor's cause in mid-century England, the Ricardian socialists, were not equal to the task of distinguishing the possibilities at hand, nor explaining the input characteristics of social organization.

It is worth emphasizing, then, that the barrier to profit creation that emerges in the context of Ricardo's original argument, namely, the increasing commodification of land and landlords' likely improved understanding of possible deviations between corn prices and values, lacks an apparent analogue in the framework of the third edition of the Principles. Social relationships outside of capitalist production are particularly resistant to analysis in commodity terms, so that as long as labor production remains highly differentiated by social organization (a matter likely in times of migration from semi-capitalist to fully capitalist spheres of production), the continual introduction of labor-replacing machinery offers the promise of additions to the profit residual through a drawing down of social organizational rents. Ricardo, then, rather than the author of the dismal science, should be better thought the quintessential voice of optimism for capitalism. Should technological advance in fixed capital be a function of continued accumulation, the substitution of fixed for circulating capital would always be possible, and thus no barriers apparently exist to capitalist growth.

\section{RICARDO'S GENERAL THEORY OF PROFITS}

The general theory of profits that emerges across the three editions of Ricardo's Principles combines an analysis of commodity residuals with the assumption that rents and profits are inverse to one another. Ricardo's account of commodity values allows a distinction between natural values and market prices, and this distinction is employed here to explain the exchange between manufactures and corn in the first two editions, and then between manufactures and labor in the third, so as to account for the creation of profits in terms of the deviation of market prices from natural values during the contraction of exchange. Profits on this view are a transfer of rents when those exchanging 
commodities, corn or labor, for manufactures receive temporarily reduced rents, a result that goes essentially undetected due to the incomplete commodity status of the inputs to corn and labor production.

The general theory of profit that appears in the two distributional accounts of the Principles can be summarized in its most basic terms by focusing on the difference between a sector of production in which all inputs are paid according to their own cost of production and one in which some inputs are not so rewarded. In the former instance, namely, capitalist manufactures in the analysis above, all identifiable inputs necessary for the production of output are purchased themselves as commodities. All inputs, then, have a determinate cost of production in Ricardo's sense as a labor value established objectively in the market by the "difficulty of production," and manufacturers, accordingly, must recoup a determinate value in marketing their output, in order to remain competitive with other capitalists, given the free flow and mobility of capital. In the latter instance, in contrast, namely that of either corn production or labor production, it is not the case that all inputs to production are purchased as commodities, since neither land nor social organization, inputs to corn and labor production respectively, are fully developed as commodities. These inputs thus lack a determinate cost of production or a labor value established objectively in a competitive market, and consequently those involved in this sort of production are neither obliged to recoup a determinate value, nor are indeed necessarily aware that, from the point of view of capitalist commodity production, there exists an implicit cost of production to the input they provide indirectly in exchange. In sum, the two sectors in question might be characterized, respectively, as fully valorized and incompletely valorized sectors of production to distinguish whether or not all inputs to production are purchased as commodities.

Profits for Ricardo, therefore result from exchange between fully and incompletely valorized sectors of production. On average, capitalists can only trade when they restore their cost of production or earn positive profits. In contrast, those in incompletely valorized sectors of production, because they possess inputs which need not be purchased, may continue to exchange with capitalists though the value of what they receive is less than the cost of production of what they provide. Indeed, those in this special position do draw down their stock of noncommodity inputs in some fashion. In Ricardo's theory, this is a matter of rent payments falling below the level at which they would be paid if residual profits did not emerge, whether we speak of traditional agricultural rents to landlords in the first two editions of the Principles, or of the social organizational rents associated with certain 
groups of laborers in the third edition. Presumably, then, at some point the persistence of positive profits, with the concomitant transfer of rent to capitalists, has some impact upon those in the incompletely valorized sector. Ricardo, however, does not begin to examine the effect, since his entire emphasis rests upon the fate of profits.

It should also be noted that Ricardo does little more than consider the possibility that rents will fall and so create profits. Though it was his intuition that there was something unique in the trade between capitalists and landlords, he himself did little more than set out the boundaries of an interaction in the market between the fully valorized capitalist sector of production in which no rent was paid and that capitalist yet incompletely valorized sector in agriculture in which it was. That is, that the tenant paid a rent on a basis other than his cost of production meant that were it possible that rents fell faster than the reduction in difficulty production through withdrawal of the margin, then profits would result when capitalists in fully valorized sectors, for example, manufacturing, exchanged commodities with the incompletely valorized sector. Empirically. speaking, however, it seemed accepted in Ricardo's time by many that as stock accumulated and the population grew rents would swallow up an increasing share of national income. Conversely, then, if the margin of cultivation were withdrawn by any means, profits could be expected to take an increasing share of national income. Ricardo, thus, sought an explanation for these more than proportionate changes in distribution for given changes in the extent of trade. That rents, then, were not paid on a cost of production basis meant that land was an input of special character in corn production, so that trade with this sector on the part of those sectors of production where no such input existed possessed unique opportunities for the creation of profits. Ricardo concluded, as rents fall, profits rise.

In the third edition, focusing on the relationship between laborers and capitalists, Ricardo only began to grope toward the explanation of another source of profit. While again it was not entirely clear how the exchange of labor for subsistence commodities resulted in profit creation, nonetheless the admission of technological unemployment revealed new possibilities to Ricardo in the determination of wages. Thus, since the precedent for analysis of distribution on an other than cost of production basis had been established in the initial formulations of the profit theory of the first two editions, it is fair to complete the details of an exchange between a fully valorized capitalist sector and an incompletely valorized labor production sector, and to term the resulting account Ricardian. Specifically, the analysis of a social organizational rent, while not elaborated by Ricardo in any way whatsoev- 
er, still issues from the intuition that those earning rents might find themselves rewarded differently from those providing inputs to production on a cost of production basis. That is, the very possibility that wages might be paid below the cost of production of labor at the margin was created when Ricardo glimpsed the fact that technological unemployment placed the compensation of labor on a new footing than had been the case in the argument of the first two editions of the Principles.

These conclusions, it should be recalled, derive from reading into the Principles two distinct distributional accounts, a project made possible by analysis of the impact of the added machinery chapter on the original distributional conception of the Principles. Scholars by and large have not identified tensions between the first two and the third edition of the Principles, and have accordingly not thought it necessary to account for problems in the development of Ricardo's thinking. Operating on the assumption that there are such problems in his thought, the argument here has attempted to explain how change and adjustment in his understanding of wages might be consistent with a relatively unchanging cost production view of value and general theory of profits. It is thus this combination of changed thinking and unchanging commitment to old ideas that, from the perspective of two distinct contexts, suggests the investigation of exchange between completely and incompletely valorized sectors of production.

\section{REFERENCES}

Berg, Maxine. 1980. The Machinery Question and the Making of Political Economy, 1845-1848, Cambridge University Press, Cambridge.

Blaug, Mark. 1958. Ricardian Economics, A Historical Study, Yale University Press, New Haven.

Davis, John B. 1989. "Distribution in Ricardo's Machinery Chapter," History of Political Economy, 21, no. 4, 457-80; reprinted in David Ricardo, edited by Mark Blaug, Edward Elgar Publishing, Aldershot.

Hollander, Samuel. 1979. The Economics of David Ricardo, Toronto University Press, Toronto.

Kurz, Heinz D. 1984. "Ricardo and Lowe on Machinery," Eastern Economic Journal, 10, no. 2, 211-29.

Morishima, Michio. 1989. Ricardo's Economics, Cambridge University Press, Cambridge. 
Negishi, Takashi. 1990. "Ricardo and Morishima on Machinery," Journal of the History of Economic Thought, 12, no. 2, 146-61.

Ricardo, David. 1951-1973. The Works and Correspondence of David Ricardo, 11 vols., edited by P. Sraffa with the collaboration of M. H. Dobb, Cambridge University Press, Cambridge.

Smith, Adam. 1937. An Enquiry into the Nature and Causes of the Wealth of Nations, Modern Library, New York.

Samuelson, Paul. 1988. "Mathematical Vindication of Ricardo on Machinery," Journal of Political Economy, 96, April, 274-82. - 1989. "Ricardo Was Right!" Scandanavian Journal of Economics, 91, no. 1, 47-62. 